\title{
A review of nutritional influences on reproduction in boars, bulls and rams
}

\author{
BW Brown \\ CSIRO, Division of Animal Production, Locked Bag 1, Delivery Centre, \\ Blacktown, NSW, 2148, Australia
}

(Received 13 April 1993; accepted 16 December 1993)

\begin{abstract}
Summary - In this paper, nutritional influences on reproduction in boars, bulls and rams during prepubertal life and in the adult is reviewed. Reproductive functions in young animals appear to be more susceptible to dietary restrictions of energy and protein than in the adult and severe feed restriction may even result in permanent damage to gonadal and neural tissue. Whilst restricted feed intake in adult animals can reduce androgen secretion and semen quality, such effects are temporal as re-feeding previously underfed adult animals usually restores reproductive function. There is now considerable evidence suggesting that the influence of nutrition on reproductive processes is mediated via effects of dietary constituents on the hypothalamic-pituitary axis, although there is some indication that dietary changes may affect the testis directly. That some nutritional regimes imposed on animals can alter volume of ejaculates and androgen activity without necessarily affecting spermatogenesis, suggests that certain constituents of the diet can differentially affect the production and/or the release of $\mathrm{LH}$ and $\mathrm{FSH}$.
\end{abstract}

nutrition / reproduction / male / farm animals

Résumé - Influence de la nutrition sur la reproduction mâle chez les porcins, les ovins et les bovins. Cet article analyse les effets du régime alimentaire sur la reproduction des verrats, taureaux et béliers au cours de leur vie prépubère et adulte. La fonction de reproduction semble plus sensible aux restrictions d'énergie et de protéines chez les jeunes animaux que chez les adultes. Une restriction alimentaire sévère peut même produire des dégâts permanents au niveau des gonades et du tissu nerveux. Une alimentation restreinte des animaux adultes peut réduire la sécrétion des androgènes et la qualité de la semence. Toutefois ces effets sont transitoires car la réalimentation d'animaux adultes antérieurement mal nourris restaure leur fonction de reproduction. De nombreux arguments suggèrent aujourd'hui que l'influence de la nutrition sur la reproduction s'exerce par l'intermédiaire des composants du régime alimentaire au niveau des centres hypothalamo-hypophysaires, même si certains résultats indiquent que les changements d'alimentation ont une action directe sur le testicule. Certains régimes alimentaires donnés aux reproducteurs peuvent changer le volume de sperme produit ainsi que la production des androgènes, sans nécessairement affecter la spermatogenèse. Ceci suggère que certains constituants de l'alimentation peuvent agir différentiellement sur la production etou la secrétion des hormones LH et FSH.

nutrition / reproduction / mâle / animaux domestiques 


\section{INTRODUCTION}

The effects of nutrition on mammalian reproduction have been the subject of many reviews (eg, Blaxter, 1956; Lamming, 1969; Allden, 1970; Leathem, 1970; Dziuk and Bellows, 1983; Kemp and Den Hartog, 1989; Lindsay et al, 1990). The purpose of this paper is to review the nutritional factors that are known to influence reproduction in boars, bulls and rams, with particular emphasis on dietary components such as energy and protein that affect onset of puberty, expression of libido, testicular function and endocrinology. Certain chemical substances in some feeds can result in poisoning, and deficiencies in nutrients, such as water, dietary vitamins or minerals, can also exert deleterious effects on normal reproductive function (Underwood and Somers, 1969; Leathem, 1970; Short and Adams, 1988) but as these substances have been extensively reviewed elsewhere, they will not be considered in the present paper.

It is generally accepted that nutritional management is the main limiting or controlling factor for reproduction in many types of domestic livestock (Short and Adams, 1988). Since domestic ruminants in many parts of the world are grazed on pasture and are bred by natural service, the quality and quantity of the available feed, particularly in the period leading up to joining, are crucial for successful mating and subsequent fertilization. Pasture, however, is not always able to maintain a high rate of fertility in breeding stock due to seasonal changes in feed supply. Consequently, grazing animals encounter qualitative and quantitative deficiencies in the diet at some time each year, which can have marked effects on reproductive efficiency (Gunn et al, 1942). Indeed, the seasonal variation in testis size and body weight of Merino rams grazing pastures in the Mediterranean environment in southwestern Australia is well documented, an effect that appears to be independent of photoperiod (Masters and Fels, 1984). As testicular size has a positive correlation with the capacity to produce sperm (Oldham et al, 1978; Martin et al, 1987), it is not surprising that seasonal variation in sperm production also occurs. However, in regions in the northern hemisphere with a temperate climate, such seasonal effects on male reproduction are more influenced by changes in photoperiod than by nutrition. Superimposed upon these recurrent and short-term seasonal variations in feed supply are the occasional, prolonged periods of severe undernutrition during drought or flood. Accordingly, an understanding of the effects of nutrition per se, as well as specific effects of nutrition on the reproductive performance of farm animals during times of feed scarcity, is of economic importance for, even under the harshest of environmental conditions, nucleus herds or flocks must be maintained and managed at the lowest cost possible.

In practice, energy conservation mechanisms in animals balance out fluctuations in dietary supply by restoring body reserves during periods of feed surplus and mobilizing these body reserves during periods of scarcity (Allden, 1970). During energy deficit, the energy balance is not negative, even if the animal is mobilizing body reserves. Thus, there is a need for a constant supply of dietary amino acids, vitamins and energy for basic tissue maintenance, thermoregulation and the locomotor demands of foraging (Hervey, 1971). Once these demands are met, the remaining energy can be allocated to growth and reproduction.

Although the mechanism by which undernutrition affects testicular function is not fully understood, it has long been recognized that this process is mediated, at least in part, by the anterior pituitary gland (Jackson, 1925; Mason and Wolfe, 1930; Mulinos and Pomerantz, 1941; Samuels, 1950; Srebnik and Nelson, 1962; Root and Russ, 1972; Stewart et al, 1975; Millar and Fairall, 1976). 
From studies on prisoners of war, who developed gynecomastia and suffered from reduced testicular function as a result of prolonged, severe malnutrition, Klatskin et al (1947) and Salter et al (1947) suggested that the restriction of food produced effects either directly on the testis or indirectly via the pituitary, with a resultant decrease in androgen or "inhibin" activity. Indeed, in more recent studies, nutrition has been shown to exert quite marked effects on gonadotrophin secretion (Martin et al, 1989). However, the exact mechanisms involved in the direct effects of different planes of nutrition on testis function, particularly in regard to the response of androgen target tissues such as the seminiferous tubules, remain elusive.

\section{NUTRITIONAL STATES IN ANIMALS}

Provided the intake is correct, an adequate diet is one in which the balance of nutrients in the diet will maintain normal health and function (Jöchle and Lamond, 1980). For domestic animals, such a diet is referred to as maintenance requirements and supports a condition of nitrogen and carbon equilibrium. On the other hand, production requirement is the amount of food needed to produce an increase in growth, milk or wool production, or an expected level of work for any individual animal (Tribe and Cumming, 1955). Thus, the type and composition of the required end product is an important factor in determining the type of nutrients that must be supplied to the animal in food.

Deficiencies in the quantity of food available, but not necessarily the quality, leads to undernutrition (Reid, 1990). Hence, undernourished animals are those that do not receive sufficient amounts of an adequate diet to meet specific requirements such as pregnancy, lactation or sperm production. Undernutrition, therefore, is primarily an energy deficiency and because it is a disease (from a nutritional view point) associated with loss of body weight, undernourished animals are at risk. In the literature, several terms such as undernutrition, underfeeding, restricted feeding, sub-maintenance or low energy intake are used to describe the nutritional limitations placed on animals which ultimately result in the animal being in an undernourished condition.

In contrast, malnutrition is a disease which occurs when the quality of food available, but not necessarily the quantity, is inadequate to meet requirements (Reid, 1990). More specifically, it constitutes food deficiencies of protein, essential amino acids or fatty acids, minerals or vitamins, or may be due to chemical imbalances which prevent the animal from utilizing certain essential nutrients. Inanition in animals is characterised by a state of physical exhaustion, which is caused by lack of nourishment or the inability to assimilate food and may arise through prolonged undernutrition or malnutrition.

In practice, there is no reason why any such deficiencies should occur in hand-fed domestic livestock such as pigs, as trace elements and vitamins are routinely incorporated in proprietary feed mixtures. The situation in the grazing animal, however, is quite different as deficiencies in the intake of nutrients can occur.

\section{INFLUENCE OF NUTRITION DURING PREPUBERTAL LIFE ON GROWTH AND SEXUAL DEVELOPMENT IN MALES}

Although the attainment of puberty in the first breeding season is less important in the male than in the female for determining future productivity, it could be important in selection programs designed to shorten the generation interval. Puberty, however, has been difficult to define because as it does not necessarily represent a specific time in life. Rather, it is a period during which matu- 
ration of various physiological, biochemical and behavioural processes occur that, in males, support completion of spermatogenesis, expression of libido and accomplishment of normal ejaculation. Nevertheless, it is agreed that puberty in larger domestic animals, and in man, is not synonymous with sexual maturity or adult status, which occurs months or even years later (Amann, 1981) when full reproductive capacity is attained.

In general, immature animals are more susceptible to nutritional deficiencies in terms of reproductive effects than the adult and, in some circumstances, may suffer permanent damage to the reproductive function (Ferrell, 1991). In prepubertal life, the result of undernutrition is generally to retard sexual development, delay the time of onset of puberty, retard the appearance of the external genitalia and suppress spermatogenesis (Mason, 1939; Anderson, 1945; Spies, 1958; Bratton et al, 1959; Reid, 1960; Baronos et al, 1969; Leathem, 1970). It appears that Sertoli cells and the proliferation of undifferentiated germ cells and spermatogonia may not be significantly impaired, though the latter germ cells can be affected after extreme undernutrition (Mason, 1939). Differentiation of the more mature germ cells may be inhibited (Siperstein, 1921; Jackson, 1932), as was evidenced in young rats underfed from 3 weeks of age, in which spermatogenesis was arrested at the primary spermatocyte stage for up to $400 \mathrm{~d}$ (Siperstein, 1920).

\section{Boars}

With boars, age appears to be more important than body weight in determining the onset of puberty, which occurs in most breeds at approximately $200 \mathrm{~d}$ of age (Rattray, 1977). An exception appears to be breeds of Chinese pigs, including Meishan, Jinhua, Dahuabai and miniature types such as Bama Xiang, all of which attain puberty closer to $100 \mathrm{~d}$ than $200 \mathrm{~d}$ of age (Kato and Harayama, 1990; Lang et al, 1992; Liu et al, 1992; Wang et al, 1992). In general, maintaining boars on low planes of nutrition for various lengths of time from weaning resulted in a delay in body and testicular growth and impaiment to development of testicular cells and spermatogenesis (table I).

Phillips and Andrews (1936) and Niwa (1954) reported that the reduction division of spermatocytes was delayed in underfed boars, with secondary spermatocytes appearing in the germinal epithelium approximately 4-6 weeks later than in normal-fed controls. Furthermore, spermatozoa collected from the cauda epididymis of the underfed boars were inactive at 5 months of age and, while normal motility of spermatozoa was generally in evidence by 7 months, some of the underfed animals still had no spermatids at 10 months of age (Niwa, 1954). Severe underfeeding of young boars from 2-3 weeks of age for $1 \mathrm{yr}$ (Dickerson et al, 1964) resulted in even more serious effects on the testis (table I). These workers reported that the cytoplasm of the interstitial cells had begun to shrink from 1 month after undernutrition commenced and had disappeared after 3 months on the restricted diet. From that time, it was impossible to distinguish the nuclei of likely interstitial cells from those of lymphocytes (Dickerson et al, 1964). Upon re-feeding, spermatogenesis developed much more rapidly than did the reappearance of Leydig cells, which ultimately developed in normal amounts once the pigs reached $120 \mathrm{~kg}$ liveweight.

Protein-energy (calorie) deficient feeding of boars from about 3 weeks of age (Platt and Stewart, 1967) resulted in marked, and possibly, permanent damage to the testes even after 40-50 d on the diet. The most distinct changes were evident in the interstitial cells (Leydig cells) in which the cyto- 
Table I. Effects of low planes of nutrition on growth and reproductive development of young boars, changes relative to normal-fed controls.

Observation

Body growth retarded

Testicular growth retarded

Testicular morphology impaired development ofSeminiferous tubules

Germinal epithelium

Tunica dartos muscle

Interstitial cells

\section{Spermatogenesis}

Reduction division of spermatocytes delayed

No spermatogenesis

Sperm motility impaired for up to 10 months

\section{Reference}

Phillips and Andrews (1936) a

Dutt and Barnhart (1959) $b$

Philips and Andrews (1936)

Niwa (1954) c: Dickerson et al (1964) d

Phillips and Andrews (1936)

Phillips and Andrews (1936)

Dickerson et al (1964)

Niwa (1954)

Dickerson et al (1964)

Niwa (1954)

\footnotetext{
a Low plane of nutrition from weaning; b boars fed from weaning for $312 \mathrm{~d}$ at 70 and $50 \%$ of the standards recommended by the US National Research Council, ie a ration of yellow maize $(75 \%)$, soya bean meal $(22 \%)$, minerals and vitamins with a crude protein content of $16 \%$; $c$ undernutrition from weaning; ${ }^{d}$ undernutrition from 2-3 weeks of age for $1 \mathrm{yr}$.
}

plasm was markedly reduced. In these celis, the diameters were only $1 / 2$ to $2 / 3$ those of the controls and the nuclei were small and crowded together. This effect on the Leydig cells persisted beyond puberty and was apparent in older boars that had been maintained on this diet, despite the fact that their testes had undergone a 'spectacular' increase in size. Presumably, such testicular growth was due to an increase in length and diameter of the seminiferous tubules, many of which at this stage had developed a lumen and contained numerous spermatocytes but few spermatids (Platt and Stewart, 1967). Also, it appeared that the protein-calorie deficiency produced detrimental effects on may endocrine glands, including the pituitary (see later section on gonadotrophins), such that the morphological changes observed in the anterior lobe were consistent with impaired hormonal secretion.

\section{Bulls}

In contrast to boars, the onset of puberty in bulls appears to be influenced more by body weight than by age (Allden, 1970; Dyrmundsson, 1973; Young, 1974; Rattray, 1977). However, other findings indicate that body weight and age at puberty are influenced by level of nutrition and post-weaning rate of gain (see Ferrell, 1991). In general, dairy and beef breeds maintained on low planes of nutrition (James, 1950; Davies et al, 1957; Flipse and Almquist, 1961; VanDemark et al, 1960; Hiroe et al, 1964; VanDemark and Mauger, 1964; Almquist, 1982; Gauthier and Berbigier, 1982) from birth or weaning for periods up to $7 \mathrm{yr}$, grew at a slower rate and therefore attained puberty later than their normal-fed or high-plane counterparts, as evidenced by delayed development of the testes, the seminal vesicles, the ampullae and the epididymides 
Table II. Effects of low planes of nutrition on growth and reproductive development of young bulls, changes relative to normal-fed controls.

\begin{tabular}{|c|c|}
\hline Observation & Reference \\
\hline Testicular growth retarded & $\begin{array}{l}\text { Davies et al (1957) } \\
\text { Pakenas and Pilipavicute (1966) }\end{array}$ \\
\hline $\begin{array}{l}\text { Development of seminal vesicles } \\
\text { (ampullae, epididymides) retarded } \\
\text { Testicular morphology impaired development of: }\end{array}$ & Davies et al (1957) \\
\hline Seminiferous tubules & Davies et al (1957) \\
\hline Tunica dartos muscle & Phillips and Andrews (1936) \\
\hline Interstitial cells & Davies et al (1957) \\
\hline Germinal epithelium unaffected & $\begin{array}{l}\text { Bratton et al (1959) } \\
\text { Davies et al (1957); Flipse and Almsquist (1961) }\end{array}$ \\
\hline Ejaculate volume reduced & $\begin{array}{l}\text { Hiroe et al (1964) } \\
\text { VanDemark et al (1964) }\end{array}$ \\
\hline Spermatogenesis & \\
\hline Sperm production reduced & $\begin{array}{l}\text { VanDemark et al (1964) } \\
\text { Pakenas and Pilipavicute (1966) }\end{array}$ \\
\hline $\begin{array}{l}\text { Sperm morphology unaffected } \\
\text { Sperm motility reduced temporarily }\end{array}$ & $\begin{array}{l}\text { James (1950); Pakenas and Pilipavicute (1966) } \\
\text { Flipse and Almquist (1961) } \\
\text { Pakenas and Pilipavicute (1966) }\end{array}$ \\
\hline
\end{tabular}

and a reduction in the volume of ejaculates (see table II). Additionally, seminal concentrations of fructose, total nitrogen, ascorbic acid and acid-soluble phosphorus as well as calcium are also reduced in bulls fed lowplane diets (Hiroe et al, 1964).

On the other hand, whilst the higher energy diets advanced puberty and hastened testicular development and function (see table III), it did not enhance ultimate testis size (Almquist, 1982). These findings conflict with those of Pruitt et al (1986), who concluded that higher levels of dietary energy fed to Simmental and Hereford bulls from weaning (about $211 \mathrm{~d}$ of age) did not hasten sexual development (as assessed from testosterone concentrations), age at first mating or age at puberty. These workers claimed that the energy levels fed to the animals (low 3.2-3.5, medium 4.2-4.6 and high 5.3-5.7 MJ metabolizable energy (ME) per bull daily) may not have been large enough to affect endocrine changes that had begun several months before the com- mencement of the trial. However, an alternative explanation is that these animals had already reached puberty since they were $211 \mathrm{~d}$ of age at the outset of the trial. Continuous overfeeding or intensive feeding of young bulls can result in lowered reproductive performance (Schilling and Krajnc, 1964; Young, 1974; see table III). In such over-fed animals, it is possible that additional scrotal lipid and/or deposition of fat around the pampiniform plexus resulting from high energy (concentrate) diets, may impair thermoregulation of the scrotal contents thereby reducing epididymal sperm reserves (Coulter and Kozub, 1984) and presumably sperm production. However, in such a circumstance, it is likely that morphological abnormalities in spermatozoa in the ejaculates would also be encountered.

Severely reducing protein (from 8.09 to $1.35 \%$ ) in the diet of young beef bulls, by either a progressive reduction over many months or instantly to a level of $1.61 \%$ (Meacham et al, 1963), or by feeding protein-free 
Table III. Effects of high energy diets or continuous overfeeding on growth and reproductive development of young bulls, changes relative to normal-fed controls.

\begin{tabular}{|c|c|}
\hline Observation & Reference \\
\hline Body growth increased & Schilling and Krajnc (1964) ${ }^{a}$ \\
\hline \multirow{3}{*}{ Testicular growth increased } & Almquist (1982) \\
\hline & Pakenas and Pilipavicute (1966) \\
\hline & Schilling and Krajnc (1964) \\
\hline \multirow{2}{*}{\multicolumn{2}{|c|}{$\begin{array}{l}\text { Development of seminal vesicles } \\
\text { (ampullae, epididymides): }\end{array}$}} \\
\hline & \\
\hline Hastened & Davies et al (1957) \\
\hline Reduced & Schilling and Krajnc (1964) \\
\hline \multicolumn{2}{|c|}{ Testicular morphology impaired development of : } \\
\hline Seminiferous tubules & Davies et al (1957) \\
\hline Tunica dartos muscle & Phillips and Andrews (1936) \\
\hline Interstitial cells & Davies et al (1957) \\
\hline \multirow{2}{*}{ Germinal epithelium unaffected } & Bratton et al (1959) \\
\hline & Davies et al (1957); Flipse and Almquist (1961) \\
\hline \multirow[t]{3}{*}{ Ejaculate volume reduced } & Hiroe et al (1964) \\
\hline & VanDemark et al (1964) \\
\hline & Schilling and Krajnc (1964) \\
\hline \multicolumn{2}{|l|}{ Spermatogenesis } \\
\hline \multicolumn{2}{|l|}{ Sperm production: } \\
\hline Increased & Almquist (1982) \\
\hline Reduced & Schilling and Krajnc (1964) \\
\hline \multicolumn{2}{|l|}{ Sperm morphology: } \\
\hline Unaffected & Hentges et al (1964) \\
\hline Abnormalities & Mwansa and Makarechian (1991) \\
\hline Sperm motility increased & Almquist (1982) \\
\hline Epididymal sperm reserves reduced & Coulter and Kozub (1984) \\
\hline
\end{tabular}

a Continuous overfeeding of bull calves from 3 weeks of age for $1 \mathrm{yr}$.

(urea-containing) diets to young beef bulls for several years (Johnson et al, 1971), resulted in reduced sperm-producing capacity but had no apparent detrimental effect on sperm motility or the percentage of abnormal spermatozoa (see table IV). As the bulls on the urea-containing diet maintained normal levels of sexual activity, with the result that their subsequent fertility was unaffected, Johnson et al (1971) concluded that protein is not essential in the diet of beef bulls to attain normal fertility. Presumably with ruminants fed diets in which urea serves as the only source of dietary nitrogen, the ruminal microbes and the host ani- mal itself are capable of synthesizing the nitrogenous compounds needed to support reproductive processes (Oltjen et al, 1971). Indeed, earlier work on underfeeding young bulls (Baronos et al, 1969) showed that the content of non-protein nitrogen, vitamin $A$ and carotene in the blood of the underfed animals was no different from that of the normal-fed controls, even though the concentrations of most of the free amino acids (13 out of 16) and glucose was reduced.

Experiments which involve reversing planes of nutrition have produced some controversial results. Increasing the plane 
Table IV. Effects of low-protein diets and protein-free (urea-containing) diet on growth and reproductive development of young bulls, changes relative to normal-fed controls.

Observation

\section{Reference}

Meacham et al (1963) a; Johnson et al (1971) b Johnson et al (1971)

Meacham et al (1963)

Meacham et al (1963)

Meacham et al (1963); Johnson et al (1971)

Meacham et al (1963); Johnson et al (1971)

Meacham et al (1963); Johnson et al (1971)

Johnson et al (1971)

Meacham et al (1963)

a Protein reduced from 8.09 to $1.35 \%$ in the diet of young bulls over many months or instantly to a level of $1.61 \%$; b protein-free (urea-containing) diets fed to young beef bulls for several yr; $c$ lower libido associated with weakened condition rather than any actual loss of sexual desire (Meacham et al, 1963).

of nutrition in former low-plane-fed bulls enhanced their sperm production which proceeded at a faster rate than their increase in body weight (James, 1950). In contrast, VanDemark et al (1964) reported that refeeding bull calves for $1 \mathrm{yr}$ with $100 \%$ TDN, that were previously fed a low-plane diet (60\% TDN) from 8 weeks to 46 months of age had no effect on improving testis growth, semen volume or sperm production, despite the fact that during the period of refeeding, these animals grew to reach $90 \%$ of the mean body weight of the normal-fed controls. In previously protein-deficient yearling bulls, the return of the animals to an adequate diet for at least 6 weeks resulted in an increase in body weight, a recovery of normal secondary sex gland function as evidenced from their normal concentrations of fructose, citric acid and 5-nucleotidase activity and, although semen volume increased, the adequate diet did not induce an elevation in the concentration of spermatozoa (Meacham et al, 1963). The failure of re-feeding to induce full reproductive function in previously underfed young animals, may reflect some degree of damage to neural centres controlling reproduction due to deficiencies in dietary components early in life or to impaired ability of the animals to synthesise adequate protein which appears necessary to facilitate the action of hypothalamic-releasing factors (Watanabe et al, 1968; Leathem, 1970).

\section{Rams}

An adequate plane of nutrition is also of vital importance for normal development of ram lambs and the rate of sexual development is highly dependent on the growth rate of the animal. As with bulls, growth and subsequent body weight appears to be a better guide to the onset of puberty in rams than age (Dunn, 1955; Watson et al, 1956; Courot, 1962; Moule, 1970; Dyrmundsson, 1973; Rattray, 1977). Depending on the breed and sensitivity to photoperiodic stimulation, this body weight may vary from 40 to $70 \%$ of adult body weight (Rattray, 1977). 
From controlled feeding experiments (Ragab et al, 1966; Pretorius and Marincowitz, 1968), it has been shown that rams reared on higher planes of nutrition attained puberty (age at which sperm first appeared in the ejaculate) at younger ages (Merino: $191.4 \pm 7.1 \mathrm{~d}$ ) and at heavier body weights $(28.6 \pm 1.1 \mathrm{~kg})$ than rams on lower levels of feeding (Merino: $2.19 \pm 7.7 \mathrm{~d}$ and $24.7 \pm 0.5 \mathrm{~kg}$, respectively). Further, the low-plane rations considerably delayed descent of the testicles, penile development and first appearance of spermatozoa in the ejaculate (Pretorius and Marincowitz, 1968). As these processes are androgen-dependent, it was concluded that restricted feeding had inhibited gonadotrophic hormone release which resulted in a decrease in androgen activity (Pretorius and Marincowitz, 1968).

Season of birth as well as season per $s e$, through variations in feed availability, can also markedly influence subsequent growth and reproductive development of rams. However, such nutritional effects may be overridden by seasonal photoperiodism (Courot et al, 1975). Suffolk, cross-bred (Skinner and Rowson, 1968) and Clun Forest (Dyrmundsson and Lees, 1972) ram lambs born in late summer were found to have smaller body weights, smaller testes with seminiferous tubules of reduced diameters and secreted androgens later, than those born in spring. Spermatogenesis appeared to be unaffected by time of birth. These effects were attributable to fluctuations in nutritional conditions during rearing, with the late-summer-born lambs suffering primarily through reduced energy intake (Skinner and Rowson, 1968) and consequently affecting earliness of puberty (Dyrmundsson and Lees, 1972). However, variations in pituitary $\mathrm{LH}$ content due to photoperiodic effects of season (Courot et al, 1975) may also have contributed to differential rates of testicular growth. Young Merino rams grazing pasture in the Mediterranean environment of south-western
Australia over 13 months and raised in isolation from ewes from about 7 months of age, gained and lost testis size at a greater rate than liveweight during winter/spring and summer autumn, respectively (Masters and Fels, 1984). The $60 \%$ decrease in testis size and the loss in body weight appeared to be independent of photoperiod and was mainly associated with a decline in the energy and protein content of the pasture over summer and autumn (Masters and Fels, 1984). At this time, the nitrogen content of the pasture may be as low as 0.7 to $2.0 \%$ (Fels et al, 1959), which is far less than that required for maximum testicular growth (Braden et al, 1974; Oldham et al, 1978).

\section{INFLUENCE OF NUTRITION ON REPRODUCTIVE FUNCTION IN MATURE MALES}

The reproductive organs of the adult male are more resistant to dietary changes than are those of the immature animal (Leathem, $1970,1975)$. In general, most of the nutritional-induced changes to reproductive function in adult boars, bulls and rams are temporary but their severity can vary from little effect on seminal characteristics and/or libido to infertility. Similarly, overfeeding of sires, as is sometimes practiced in preparation for sale or 'show', can also have detrimental effects on reproductive capacity (Skinner, 1981). Clearly, the degree of undernutrition or of overfeeding imposed as well as its duration, contributes to these disparate responses, but in most instances reproductive function returns to a normal or near-normal state upon resumption of a standard diet.

\section{Boars}

Much of the work on nutrition in mature boars has been conducted in relation to body composition and establishment of 
balanced diets designed for intensive rearing. There are few studies on nutrition-reproduction interactions in mature boars. Kemp and Den Hartog (1989) concluded from their review on this subject, that energy or protein intake had little effect on libido or on sperm quality in mature boars, except when the condition of the animal became extremely poor as a result of prolonged undernutrition. Moreover, studies on the influence of protein intake on the number of sperm cells in the ejaculates of mature boars have produced contradictory results.

Stevermer et al (1961) fed 22-month-old Yorkshire boars on different levels of feed intake for 15.5 months. Over this period, the animals fed ad libitum (74.5 MJ digestible energy (DE)/d) a diet recommended by the National Research Council (NRC) for adult boars gained $136 \mathrm{~kg}$, those on $100 \%$ of NRC (40.2 MJ DE/d) gained $39 \mathrm{~kg}$, whilst those on low plane (initially $75 \%$, then $50 \%$ of NRC) lost $60 \mathrm{~kg}$ liveweight. They found that the restricted feed intake resulted in a marked reduction in semen volume whilst full-feeding did not increase semen volume over that obtained on the medium plane of nutrition. Further, as the concentration of spermatozoa increased with decreasing volume, the number of spermatozoa per ejaculate was little affected by the plane of nutrition. This suggested that the output of the accessory glands, but not the output of spermatozoa by the testes, was affected by the reduced feed intake and is likely to reflect a suppression of androgen secretion, and therefore androgen stimulation, of the accessory glands (see later). Moreover, neither motility nor fertility (appraised from artificial insemination trials) of freshly ejaculated spermatozoa obtained from boars on the restricted diet was affected over the prolonged period. This indicated that widely varying planes of nutrition can be tolerated by adult boars without detrimental effects on spermatogenesis (Stevermer et al, 1961), provided they are not permitted to become physically weak.

\section{Bulls}

Restricted feeding of mature Dexter bulls over a period of 23 weeks, such that the bulls lost $6.5 \mathrm{~kg}$ liveweight per week had no observable effect on volume and density of semen, or motility and morphology of spermatozoa (Mann and Walton, 1953). On the other hand, feeding a low protein diet to adult bulls for about $1 \mathrm{yr}$, resulted in smaller testes and epididymides than control bulls and their gonadal and extragonadal reserves of spermatozoa were reduced to $70-75 \%$ of that for control buils (Laszczka et al, 1969a,b). Though the volume of ejaculates and the percentage of live spermatozoa were also in decline after 8 months on this diet, there were no apparent morphological changes in the spermatozoa (Laszczka et al, 1969a). From studies in mature dairy bulis (Branton et al, 1947; Shirley et al, 1963), it appears that a concentrate mixture containing approximately $12 \%$ protein, when fed with mixed hay, will supply sufficient protein for maintenance of body weight as well as satisfactory semen production. Increasing the protein content of the diet to $20 \%$ had no additional, beneficial effect on semen quality in bulls (Shirley et al, 1963).

Normally, underfeeding does not affect the sexual desire of bulls unless it becomes extreme, or continues over a long period of time (Walker, 1967). However, long-term feeding of bulls on low protein rations, or overfeeding of bulls, can reduce their libido compared with that of bulls fed either normal or above normal rations (see table $V$ ).

\section{Rams}

A distinct cyclical pattern of changes in liveweight (Russel et al, 1976; Masters and Fels, 1984) and testis size (Masters and Fels, 1984) throughout the year is apparent 
Table V. Effects of different diets on sexual activity in mature bulls, changes relative to normal-fed controls.

\begin{tabular}{lll}
\hline Diet & Sexual activity & Reference \\
\cline { 2 - 3 } Undernutrition & Unaffected a & $\begin{array}{l}\text { Walker (1967) } \\
\text { Wierzbowski (1978) }\end{array}$ \\
High energy diet & Unaffected & Mwansa and Makarechian (1991) \\
Low protein diet & Reduced libido b & Meacham et al (1963) \\
Overfeeding & Reduced libido c & Flipse and Almquist (1961) \\
& & Hentges (1967); Walker (1967) \\
\hline
\end{tabular}

a Unaffected unless underfeeding becomes extreme or continues over a long period of time; b reduced libido appeared to be associated with an increase in physical weakness due to emaciation; c lower libido appeared to be due to lack of physical strength associated with their excessive fatness. Effect on libido can be reversed on resumption of normal maintenance diet but may be permanent if animals are kept overfat beyond $2 \mathrm{yr}$.

in grazing rams, with maximum values occurring soon after the time of greatest feed production. Several studies on nutrition in rams have demonstrated that 'improved' diets result not only in heavier liveweights, but also in enhanced testis size and sperm production (Lindsay et al, 1976; Oldham et al, 1978; Martin et al, 1987; Cameron et al, 1988). However, as these diets comprised increased amounts of both digestible energy and protein, in addition to minerals and vitamins, it was not possible to determine whether specific component(s) of the diet contributed to the observed reproductive effects.

Restricted feeding of rams for 3 months, which resulted in a reduction of body fat to less than $12 \%$ of liveweight compared with $25-49 \%$ in well-fed controls, produced a decrease in testis weight, smaller seminiferous tubule diameters and lower numbers of sperm in the epididymides than in well-fed control rams (Setchell et al, 1965). The relative reduction in testicular weight was more severe than the decline in body weight (Setchell et al, 1965). The volume of ejaculates and the motility and density of the contained spermatozoa (Comstock and Brady, 1937;
Parker and Thwaites, 1972) were also markedly reduced in rams on restricted feed intake.

In a study on sperm production, in which 2 levels of dietary energy and/or protein (made resistant to ruminal degradation) were fed to mature Merino rams, Braden et al (1974) found that daily sperm production was unaffected by increasing protein intake alone but was significantly enhanced by increasing either the intake of energy alone or both protein and energy. They also showed that rams fed high energy diets had significantly larger testes and seminal vesicles than those on low energy diets, while the level of protein had no material effect on these parameters (Braden et al, 1974). Accordingly, it was concluded that a high protein intake is not essential for high sperm production in rams. Further, it was suggested that energy intake probably had no affect either on spermatogenesis or on testosterone production directly, but may influence these parameters via an effect on gonadotrophin secretion. Rowe and Murray (1984) and Murray et al (1990) also concluded from their studies on the effect of high energy and protein intakes in rams, 
that digestible energy intake is the most important nutritional factor influencing testicular growth.

Nevertheless, an adequate source of nitrogen in the diet is essential to facilitate normal reproductive function and it appears that rams are able to utilize a ration with only urea nitrogen for metabolism of protein synthesis (Warnick et al, 1961). Feeding adult rams for 37 weeks on a diet containing about $60 \%$ of the protein comprising a standard feeding ration, Okólski et al (1971) reduced semen volume $(54 \%)$, the total number of spermatozoa in the reproductive organs $(77 \%)$ and the percentage of spermatozoa that were progressively motile $(49 \%)$ compared with normal-fed control rams. Histological examinations of the testes revealed swelling and hypertrophy, atrophy of the seminal epithelium and a reduction in the number of Sertoli cells. Degeneration of some seminiferous tubules was characterised by the presence of pyknotic nuclei in some cells and numerous small vacuoles in the cytoplasm. Additionally, pathological changes were also noted in the epididymides (Okólski et al, 1971). A complete lack of nitrogen in the diet eventually leads to death, but rams can survive nitrogen deficiency for considerable periods without there being any detrimental effects on sperm morphology or motility, though eventually ejaculate volume and the total number of sperm cells decline (Warnick et al, 1961) as the testes and seminiferous tubules degenerate (Mori, 1959).

Sexual activity of rams can be influenced by nutrition but generally the effects are observed only after prolonged undernutrition and marked loss in body weight. Salamon (1964) claimed that sexual drive was more intense in rams fed a high protein than a low protein supplement. On the other hand, several workers have reported that rams fed sub-maintenance diets exhibited reduced sexual activity (Parker and Thwaites, 1972; Mattner and Braden, 1975;
Alkass and Bryant, 1984) and it was concluded that if a diet supplied adequate energy, a high protein supplement would have no beneficial effect on sexual motivation (Mattner and Braden, 1975). As underfed rams maintain an interest in oestrus ewes and mount at the first opportunity, their reduced libido appears to be more a consequence of general muscular weakness (Parker and Thwaites, 1972) rather than an effect of the restricted diet on the neural centres controlling libido. Nevertheless, the evidence suggests that when rams are not in good body condition, supplementary feeding in the 2 months prior to joining may improve their reproductive performance over the subsequent mating period through a beneficial effect on sperm output and libido, both of which can influence the coverage of oestrous ewes (Mattner and Braden, 1975).

\section{NUTRITIONAL INFLUENCES ON REPRODUCTIVE ENDOCRINOLOGY IN MALES}

It was shown many years ago that chronic inanition in mature rats resulted in complete failure of reproductive activity and an endocrine pattern resembling that in hypophysectomized animals (Mulinos and Pomerantz, 1940). Treatment of such underfed animals with chorionic gonadotrophins (rich in $\mathrm{LH}$ ) was at least partially effective in restoring the weight and function of the reproductive organs of rats (Mason and Wolfe, 1930; Mulinos and Pomerantz, 1941; Lutwak-Mann and Mann, 1950) and bulls (Davies et al, 1957). Further, in underfed male rats (Mulinos and Pomerantz, 1941) and dogs (Pazos and Huggins, 1945), the accessory organs were responsive to androgen stimulation, as evidenced by their increase in weight, despite continued inadequate feeding. These studies indicate that the mechanism by which prolonged undernutrition results in testicular atrophy is 
mediated, at least in part, by the anterior pituitary gland and led to the description of the condition as 'pseudohypophysectomy' (Mulinos and Pomerantz, 1941). However, these early studies could not elucidate whether undernutrition merely decreased hormone synthesis or release, or whether the observed effects were due to insufficient substrate for the target organs to function normally. From more recent studies (see below), it now appears that restricted feeding inhibits gonadotrophic hormone release with a resultant decrease in androgen activity. Further, restricted energy intake early in life may prevent or slow the maturational processes at the pituitary-hypothalamus level (Short and Adams, 1988).

\section{Gonadotrophins}

Changes in body growth and testis size of rams have been associated with seasonal variations in the pattern of $\mathrm{LH}$ secretion (Lincoln, 1979). Whilst there is general agreement that underfeeding in males reduces $\mathrm{LH}$ secretion, the involvement of this hormone in facilitating nutrition-induced increases in testis size remains controversial.

In mature rams, diets which were formulated to provide either $50 \%$ above or $25 \%$ below maintenance requirements in protein (5.5\% digestible crude protein) but equivalent levels of energy (7.2 MJ DE/d), had no effect on testis size but the rams fed the 'low' protein diet had significantly fewer LH pulses than those on the 'high' protein diet (Lindsay et al, 1984). Similarly, a significant decrease in $\mathrm{LH}$ pulses was also observed in rams fed a low energy ration compared with those on a maintenance diet (Martin et al, 1989). In 13-month-old Creole bulls fed either a high or a low concentrate ration, which supported mean daily growth rates of 780 and $370 \mathrm{~g}$, respectively (Gauthier and Berbigier, 1982), the lower ration resul- ted in reduced mean plasma $\mathrm{LH}$ and testosterone concentrations. This effect appeared to be due to a significant reduction in the number of pulses of these hormones per d (LH: 2.55 vs 0.63; T: 2.50 vs 0.75 pulses per d, $P<0.05$ ), without there being any alteration in their basal levels. Thus the reduced LH pulsatility in the underfed animals may have resulted from an effect of the diet on either the hypothalamic 'pulse generator' or on the sensitivity of the pituitary to GnRH stimulation. However, the finding that the secretory $\mathrm{LH}$ response of the pituitary to an injection of synthetic LHRH was greater in underfed animals than in those fed control diets (Campbell et al, 1977; Beal et al, 1978; Gauthier and Berbigier, 1982) suggests that the reduction in LH pulsatility observed in the slower growing underfed animals may be due primarily to a decrease in release of hypothalamic hormones that control anterior pituitary function (Campbell et al, 1977; Gauthier and Berbigier, 1982). Such a circumstance may also have the effect of reducing the pituitary stores of $\mathrm{LH}$, which was reported to occur in rams maintained on a low energy diet (Alkass et al, 1982), though interestingly, there was no concomitant decrease in pituitary $\mathrm{FSH}$ content. In contrast, in male rats, underfeeding for 10-20 d resulted in an increase in pituitary concentration of $\mathrm{LH}$, but not $\mathrm{FSH}$, which suggested that in this species, underfeeding impaired release mechanisms for $\mathrm{LH}$ (see above, decrease in $\mathrm{GnRH}$ pulsatility) rather than factors controlling hormone synthesis (Howland, 1975).

To elucidate the physiological mechanism(s) mediating such endocrine responses during undernutrition, Gauthier and Coulaud (1986) studied LH pulsatility in adult bulls fed high and low planes of nutrition, before and after castration and after replacement therapy with testosterone in the castrates. They found that after castration, there was a marked increase in LH pulsatility in both groups and that the previous inhi- 
bition of LH pulsatility, induced by undernutrition, disappeared. After treatment with $30 \mathrm{mg}$ testosterone per $\mathrm{d}$ for 2 weeks, which produced the same plasma levels of this hormone in the 2 groups, marked suppression of LH pulsatility in the underfed animals was reimposed. A similar finding has been reported in rams (Tjondronegoro et al, 1991), in which the effects of both testosterone and bovine follicular fluid were studied after castration. Accordingly, it appears that the effects of undernutrition on gonadotrophin released may be mediated by hypersensitivity of the hypothalamopituitary axis to testosterone. Presumably therefore, even the reduced testosterone concentrations that occur as a result of underfeeding are sufficient to exert this endocrine effect.

The increase in testis size in bulls (Nolan et al, 1990) and rams (Ritar et al, 1984; Martin et al, 1987) resulting from feeding high energy diets (including diets supplemented with $750 \mathrm{~g}$ lupin grain) is not accompanied by a sustainable elevation in either pulsatility or mean concentration of LH. However, when rams were fed much larger amounts of lupin grain or cowpeas ( $2 \%$ of body weight) for $77 \mathrm{~d}$, plasma LH concentrations were significantly elevated compared with that in hay-fed controls (Pomares et al, 1991). Martin et al (1990) reported that in rams fed a sub-maintenance diet for 2 months (sufficient to reduce $\mathrm{LH}$ secretion during that period) and subsequently fed an extra ration which included $750 \mathrm{~g}$ of lupin grain/d, plasma LH concentrations were significantly elevated $2 \mathrm{~d}$ after commencement of the extra ration. However, it is possible that this increase in LH was merely a 'rebound' response which can occur following temporary suppression of hormones; such a response was reported for both $\mathrm{LH}$ and $\mathrm{FSH}$ in rams after temporary suppression of these hormones by treatment with epidermal growth factor (Brown et al, 1989). It also appears that glucose is not directly involved in gona- dotrophin release, since infusions of $1.4 \mathrm{M}$ glucose solutions in rams for $11 \mathrm{~d}$ failed to increase either LH or FSH (Boukhliq et al, 1991).

It appears that nutrition-induced increases in testicular size is associated with either an increase in the size and length of the seminiferous tubules (Oldham et al, 1978 ) or an increase in the number of expanded tubules (Nolan et al, 1990). These effects presumably occur as a result of more spermatogenic cells and an increase in testicular fluid secreted by the Sertoli cells in response to $\mathrm{FSH}$ and testosterone (Vitale et al, 1973; Courot and Ortavant, 1981). Though FSH concentrations were not measured in these studies, the increase in seminiferous tubule size may indicate a differential effect of nutrition on gonadotrophin release. Indeed, in rams fed $750 \mathrm{~g}$ of lupins/d in addition to a maintenance diet (Tjondronegoro et al, 1990), mean plasma FSH concentrations were significantly elevated compared with those in control animals on the maintenance diet or other rams on half maintenance. The increased values were in evidence after the fifth day of feeding and remained elevated for at least $28 \mathrm{~d}$. Interestingly, $\mathrm{FSH}$ concentrations did not differ materially between the controls rams or those on the half maintenance diet (Tjondronegro et al, 1990), a result which is in accord with earlier findings that showed there was no significant depletion in pituitary FSH content in rams fed low energy rations (Alkass et al, 1982). In Merino ram lambs supplemented with lupin grain from birth (through feeding the dams $500 \mathrm{~g} / \mathrm{ewe} / \mathrm{d}$ until weaning at 12 weeks of age) to puberty $(10 \mathrm{~g} / \mathrm{kg}$ body weight $/ \mathrm{d}$ from weaning until 28-30 weeks of age), a more sustainable increase in $\mathrm{FSH}$ plasma concentrations occurred (Brown, 1993). The mean levels of this hormone peaked about 10-20 d earlier ( $31-40 \mathrm{~d}$ of age) than that in the control lambs (51-60 d of age) and remained at an elevated level for 10-20 d longer (until 
$71-80 \mathrm{~d}$ of age) before the decline to low levels (Brown, 1993). Furthermore, mean plasma FSH concentrations remained at a significantly $(P<0.05)$ greater level in these animals than in the controls for the 14 months duration of the experiment (Brown, unpublished data).

In monogastric animals, which are more dependent upon dietary protein as a source of nitrogen than ruminants, protein-calorie deficient diets produce very marked morphological changes in the anterior pituitary (Godwin and Platt, 1960; Dickerson et al, 1964; Platt and Stewart, 1967), which were consistent with there being a reduced storage of, but not necessarily a complete absence of, trophic hormones in this gland.

\section{Androgens}

Before the advent of routine plasma testosterone assays, the weight of the reproductive accessory glands and/or the concentrations of their secretion of fructose and citric acid (which are known to be androgen dependent) were the criteria by which androgenic activity was assessed (Mann and Lutwak-Mann, 1951; Mann and Walton, 1953). From studies of the fructose and citric acid content of semen obtained from young bulls (Davies et al, 1957; Mann et al, 1967; Baronos et al, 1969), it was postulated that restricted feed intake markedly delayed the onset of testosterone production, which preceded the delay in spermatogenesis. This notion was given greater credence with the advent of testosterone assays, when Mann et al (1967) showed that the testes of undernourished young bulls contained and secreted less testosterone and had a lower testosterone/androstenedione ratio than those in normal-fed control twins. The larger amounts of androstenedione in the undernourished animals appeared to be associated with altered activity of the enzyme (17ß-hydroxysteroid dehydrogenase) involved in steroid biosynthesis (Mann et al, 1967).

Restricted feeding of mature bulls over a period of 23 weeks also resulted in marked depression of fructose and citric acid concentrations in the semen (Mann and Walton, 1953). Because, in these animals, seminal characteristics were unaffected by the treatment, it was concluded that spermatogenesis may either proceed at a lower level of testosterone production than that required for accessory gland function, or that the testes have a greater propensity for obtaining testosterone from the blood than do the accessory glands (Mann and Walton, 1953). However, later studies have shown that testosterone is present in testicular lymph (Lindner, 1963) and rete testis fluid (Voglmayr et al, 1966; Cooper and Waites, 1974; Amann and Ganjam, 1976), whilst androgen binding protein (ABP) occurs in rete testis fluid and seminal plasma (Jégou et al, 1978; Jégou et al, 1979) and accordingly, may indicate existence of extra vascular mechanisms for 'intra-gonadal' transport of androgens, whereby Leydig cell secretions can exert an influence on tubular function.

In adult Merino rams, in which restricted food intake for 3 months resulted in a reduction of body fat to less than $12 \%$ of liveweight (25-49\% for well-fed animals), mean testosterone output was also considerably reduced $(0.4 \pm$ sem $0.2 \mathrm{mg} / \mathrm{d})$ when compared with that $(3.5 \pm 0.7 \mathrm{mg} / \mathrm{d})$ for well-fed control rams (Setchell et al, 1965). This is in accord with the finding that reduced energy intake in rams resulted in a decrease in the fructose content of ejaculates (Moule et al, 1966), indicating that androgenic activity was suppressed. Setchell et al (1965) reported that the reduced testis weight in the underfed animals was accompanied by a decrease in testicular blood flow, oxygen uptake and glucose uptake. These changes in particular indicate that metabolic activity 
of the testis is also lowered during undernutrition, though the fraction of the oxygen uptake derived from oxidation of glucose was unchanged (Setchell et al, 1965). The lack of any effect of undernutrition on peripheral plasma testosterone levels in the mature Merino rams studied by Parr and Tilbrook (1990) was possibly due to the very short period of restricted feeding (10 d) which was effective in causing only a modest loss in body weight $(5.9 \%)$, much of which may be due to loss of gut-fill of water.

As alluded to earlier, increasing the dietary energy intake in young bulls (Reeves and Johnson, 1976; Nolan et al, 1990) was associated with an increase in testicular size and an elevation in both plasma and testicular testosterone concentrations, without there being any significant change in mean or basal plasma LH concentrations, or in LH pulse height frequency or amplitude (Nolan et al, 1990). Moreover, the increased energy intake also resulted in an enlargement of the Leydig cells and such growth may constitute an increase in the amount of smooth endoplasmic reticulum, thereby facilitating the observed rise in testosterone synthesis (Zirkin et al, 1980; Nolan et al, 1990). These findings imply that, in the growing bull at least, additional nutrient intake may alter Leydig cell function directly, perhaps by affecting sensitivity to gonadotrophic stimulation. In contrast, a high protein lupin grain supplement fed to Booroola and control Merino rams for $9-15$ weeks produced no significant effect on the tonic secretion of either testosterone (Ritar et al, 1984; Martin et al, 1987) or LH (Sutherland and Martin, 1980; Ritar et al, 1984; Martin et al, 1987). This finding is surprising in view of the fact that there was an increase in testis size in the supplemented rams. Martin loc cit concluded that the resulting enlargement of the testes did not appear to involve an increase in the responsiveness of the testis of LH. Presumably, the increase in testis size in these rams was associated with an increase in the volume of the seminiferous tubules (Oldham et al, 1978). The lack of an increase in testosterone concentrations may be due to the inability of this diet to affect Leydig cell function directly.

\section{THE IMPORTANCE OF AMINO ACIDS FOR REPRODUCTIVE FUNCTION IN MALES}

In ruminants, provided that metabolisable energy is not limiting, degradation of dietary protein by the rumen microorganisms provides the animal with a reasonably constant amino-acid supply (Reid, 1990), which in general, is sufficient to meet requirements for maintenance, slow growth or early pregnancy (Lloyd Davies, 1982). Additional, essential amino acids that are required to facilitate fast growth, are provided directly to the animal through the post-ruminal digestion of undegraded protein. Although certain amino acids appear to be necessary for the process of spermatogenesis (Hopwood and Gassner, 1962; Setchell et al, 1967), the grazing ruminant would not normally encounter deficiencies in these substances unless the pasture is of very low protein content. Furthermore, in adult rams, it appears that the testis is able to utilize glucose to synthesize most of the amino acids that are present in high concentrations in testicular fluid, with the possible exception of glycine (Setchell et al, 1967). This may also be the case in bulls, as Oltjen et al (1971) concluded from their studies that the young bull is capable of synthesizing all of the essential and non-essential amino acids needed for fertility, even when fed a protein-free diet in which urea served as the sole source of dietary nitrogen. On the other hand, monogastric animals, such as pigs, are extremely dependent upon dietary protein as a source of amino acids but as these animals are intensively raised and there- 
fore mostly hand fed with proprietary feed mixtures, protein deficiency should not occur.

The early work of Courrier and Raynaud (1932), Cunningham and Hopkirk (1935) and Cunningham et al (1937), which showed that rats fed a diet deficient in lysine had poorly developed testes, provided some of the first evidence that specific amino acids may be of importance for normal reproduction in males. From later work in rats, it was concluded that whilst leucine, methionine or valine did not appear to be essential for testicular function, lysine, tryptophane, phenylalanine, arginine and histidine were crucial and their absence resulted in moderate to marked histological and cytological changes in the testes and impairment of spermatogenesis (Maun et al, 1945, 1946a, 1946b; Samuels, 1950; Shettles, 1960). In boars, tryptophane deficiency also resulted in testicular atrophy, marked disorganization of the testes and the absence of spermatogenesis (Shettles, 1960), whilst increasing the amounts of lysine (Stepurin and Miruskina, 1969; Netesa and Pashkevich, 1971) or methionine (Tommé and Loskutnikov, 1972) in diets fed to boars, improved the quality and the quantity of their semen. In young bulls nearing puberty, the blood plasma content of most of the free amino acids was reduced as a result of undernutrition (Baronos et al, 1969) or feeding a purified diet containing urea as the sole source of dietary nitrogen (Oltjen et al, 1971). In the latter case, however, the amino-acid content of the seminal plasma seemed little affected by the diet and may indicate a preferential need for the available amino acids to support fertility over growth. It would appear therefore that young bulls are capable of synthesizing all of the essential and non-essential amino acids needed for fertility even when fed a protein-free (urea-containing) diet (Oltjen et al, 1971).

It is not clear how specific amino acids actually induce these reproductive effects but the mechanism may involve the hypothalamic neurones rather than any direct effect on the testis. In rats, monkeys and sheep, in vivo administration of agonists of the neuroexicitatory amino acids glutamate and aspartate induced the release of $\mathrm{LH}$ (Wilson and Knobil, 1982; Gay and Plant, 1987; Ebling et al, 1989; Estienne et al, 1990; Jansen et al, 1991), an effect which was evidently mediated by these substances triggering $\mathrm{GnRH}$ release (Bourguignon et al, 1989; Claypool and Terasawa, 1989). Moreover, it has been shown that antagonists of neuroexcitatory amino acids can inhibit the release of $\mathrm{GnRH}$ from the hypothalamus (Bourguignon et al, 1989) and suppress $\mathrm{LH}$ release (Arslan et al, 1988), while pre-treatment of monkeys with a $\mathrm{GnRH}$ receptor antagonist eliminated the ability of $N$-methyl-D, L-aspartate to stimulate $\mathrm{LH}$ release (Gay and Plant, 1987).

\section{THE EFFECTS OF PLANT OESTROGENS ON REPRODUCTIVE PERFORMANCE IN MALES}

The adverse effects that grazing 'oestrogenic' pastures has on reproduction in ewes is well known (see reviews by Moule, 1961; Moule et al, 1963). Bennetts et al (1946) claimed that the ingestion of oestrogenic pasture by flock rams did not lower their fertility. However, the findings of Moule and Mattner (1961) suggested that spermatogenesis in rams could be depressed by intramuscular injections comprising the equivalent of $25 \mu \mathrm{g}$ stilboestrol dipropionate per ram per d over 6 weeks. Such a treatment resulted in a decrease in the total number of spermatozoa in ejaculates, the motility of spermatozoa and the percentage of live and morphologically normal spermatozoa, from 5 weeks after commencement of treatment. These effects were not long lasting, for the animals showed substantial recovery in the seminal characteristics within 6 weeks of 
ceasing treatment. The oestrogen equivalent of $25 \mu \mathrm{g}$ stilboestrol used in this study exceeded the minimum oestrogen intake known to adversely affect the breeding performance of ewes (Moule, 1961) but may be within the range of normal oestrogen intakes for some animals grazing oestrogenic pastures.

Nevertheless, the above effects induced by stilboestrol treatment were not in evidence in Merino rams grazed on red-cloverdominant pasture from weaning for a period of 12 months (George and Turnbull, 1966). In these animals, puberty was not retarded, nor did the red clover have any detrimental affect on liveweight, weight of testes and epididymides or on the number of epididymal sperm when compared with control rams grazing grass-dominant pasture. In this study, it was estimated that the effective intake of oestrogenic substances obtained from grazing the red-clover pasture was greater than the equivalent of $15 \mu \mathrm{g}$ stilboestrol dipropionate per d (George and Turnbull, 1966).

With the huge amount of oestrogen that is required to produce seminal degeneration in bulls, it is unlikely that they could consume sufficient oestrogenic pasture to affect spermatogenesis (Moule and Mattner, 1961) and the evidence available indicates that cattle are unaffected by grazing oestrogenic pastures that are detrimental to reproduction in sheep (Bennetts et al, 1946).

\section{CONCLUDING REMARKS}

There seems to be little doubt that reproductive function in the young animal is more susceptible to changes in dietary energy or protein than in the adult. From early in life, reduction of these components of the diet to levels below that required to support normal body growth, can produce detrimental effects on reproductive development and under conditions of severe feed restriction, such effects may result in long-term damage to gonadal and neural tissues. In this regard, young boars appear to be more vulnerable than their ruminant counterparts and this is probably due in part to their total dependence on dietary protein as a source of nitrogen.

Restricted energy intake in adult boars, bulls and rams appears to have more of an adverse effect on accessory gland function, and therefore on androgen activity, than on spermatogenesis, whilst protein deficiency generally reduces accessory gland secretions and semen quality. However, these physiological and endocrine changes appear to be temporary, as re-feeding previously underfed adult animals unusually restores normal reproductive function. Sexual activity may be suppressed by low energy intake but the reduced levels of libido in underfed bulls and rams seems to be more a consequence of reduced physical strength, than an effect on neural centres controlling sexual activity. In general, high energy intake has beneficial effects such as advancement of onset of puberty as a result of enhanced reproductive development and increased testicular size and sperm production in both young and adult animals, whilst excessive intake can have detrimental effects on reproduction.

There is now considerable evidence suggesting that the influence of nutrition on reproductive processes are mediated via effects of dietary constituents on the hypothalamic-pituitary axis, although there is some indication that dietary changes may affect the testis directly. That some nutritional regimes imposed on animals can alter the volume of ejaculates and androgen activity without necessarily affecting spermatogenesis, suggests that certain constituents of the diet can differentially affect the production and/or release of $\mathrm{LH}$ and FSH. The findings that severe protein deficiency produces detrimental effects on semen quality may implicate certain amino acids in mecha- 
nisms controlling stimulation of FSH secretion. Indeed, studies on agonists and antagonists of neuroexitatory amino acids have demonstrated an important role played by certain of these compounds in secretion of hypothalamic-releasing factors. FSH by binding to Sertoli cells appears to stimulate the synthesis of many proteins (Sharpe, 1984) including inhibin and $A B P$. The major role of $A B P$ is uncertain but it has been suggested that it is involved in transport of androgens within the testis and concentrates them at sites that facilitate spermatogenesis (Martin et al, 1990), or that it mediates the action of gonadotrophins on Sertoli cells to enhance and promote spermatogenesis (Courot and Ortavant, 1981). However, as control of FSH secretion also involves inhibin, a study of the influence of dietary constituents on Sertoli cell function in relation to inhibin and $A B P$ production and on the responsiveness of the pituitary to inhibin, is also needed.

Attempts to elucidate the mechanism(s) by which energy intake influences testicular size and function have produced conflicting findings. Possibly this is partly due to the fact that many feeding regimes designed to produce high or low energy intakes have necessarily resulted in alteration of the protein content. Whilst it seems certain that undernutrition in animals leads to a decrease in androgen secretion and activity as a result of decreased LH release, there is convincing evidence to show that high energy diets promote increased androgen secretion (principally testosterone) in the absence of a concomitant sustainable increase in LH secretion. This suggests that high energy diets may act at the level of the testis directly by altering the size and/or function of the Leydig cell. The possibly exists that high energy intake may influence enzyme activity involved in the conversion of androstenedione to testosterone, or it may alter the Leydig cell content of smooth endoplasmic reticulum, the amount of which is highly cor- related with the total amount of testosterone produced. However, there is also some evidence to suggest that high energy intake facilitates increases in FSH secretion, which may explain the beneficial effects of such diets on spermatogenesis and sperm production. This aspect may be of particular relevance in young animals, since a rise in FSH secretion occurs concomitantly with an increase in the number of Sertoli cells during early life. Accordingly, enhancement of FSH secretion during this period may therefore permit a sustainable increase in sperm production and improve semen quality later in life, which could have the effect of reducing the huge variation in sperm production that normally occurs between potential sires.

\section{ACKNOWLEDGMENTS}

I wish to thank NR Adams, M Courot, GB Martin, WF Colebrook and KE Turnbull for helpful comments in the preparation of this manuscript. My thanks also go to PH Van Dooren for the French translation of the summary.

\section{REFERENCES}

Alkass JE, Bryant MJ (1984) Effects of level of feeding and body condition on libido in the ram. World Rev Anim Prod 20, 45-48

Alkass JE, Bryant MJ, Walton JS (1982) Some effects of level of feeding and body condition upon sperm production and gonadotrophin concentrations in the ram. Anim Prod 34, 265277

Allden WG (1970) The effects of nutritional deprivation on the subsequent productivity of sheep and cattle. Nutr Abstr Rev 40, 1167-1184

Almquist JO (1982) Effect of long-term ejaculation at high frequency on output of sperm, sexual behaviour, and fertility of Holstein bulls; Relation of reproductive capacity to high nutrient allowance. J Dairy Sci65, 814-823

Amann RP (1981) A critical review of methods for evaluation of spermatogenesis from seminal characteristics. J Androl 2, 37-58 
Amann RP Ganjam VK (1976) Steroid production by the bovine testis and steroid transfer across the pampiniform plexus. Biol Reprod 15, 695-703

Anderson J (1945) The semen of animals and its use for artificial insemination. Technical Communication, Imperial Bureau of Animal Breeding and Genetics. Experimental Station, Naivasha, Kenya

Arslan M, Pohl CR, Plant TM (1988) D, L-2-Amino5-phosphonopentanoic acid, a specific $\mathrm{N}$ methyl-D-aspartic acid receptor antagonist, suppresses pulsatile $\mathrm{LH}$ release in the rat. Neuroendocrinology 47, 465-468

Baronos S, Mann T, Rowson LEA, Skinner JD (1969) The effect of nutrition and androgens on the composition of bovine blood plasma and seminal plasma at puberty. Br J Nutr 23, 191-201

Beal WE, Short RE, Staigmiller RB, Bellows RA, Kaltenbach CC, Dunn TG (1978) Influence of dietary energy intake on bovine pituitary and luteal function. J Anim Sci 46, 181-188

Bennetts HW, Underwood EJ, Shier FL (1946) A specific breeding problem of sheep on subterranean clover pastures in western Australia. Aust Vet J 22, 2-12

Blaxter KL (1956) The nutritive value of feeds as sources of energy: A review. J Dairy Sci 39, 1396-1424

Boukhliq R, Martin GB, Adams NR (1991) Glucose infusion does not alter gonadotrophin levels in the ram. Proc Aust Soc Reprod Biol 23, 89

Bourguignon JP, Gerard A, Franchimont P (1989) Direct activation of gonadotrophin-releasing hormone secretion through different receptors to neuroexcitatory amino acids. $\mathrm{Neu}$ roendocrinology 49, 402-408

Braden AWH, Turnbull KE, Mattner PE, Moule GR (1974) Effect of protein and energy content of the diet on the rate of sperm production in rams. Aust J Biol Sci 27, 67-73

Branton C, Bratton RW, Salisbury GW (1947) Total digestible nutrients and protein levels for dairy bulls used in artificial breeding. J Dainy Sci 30, 1003-1013

Bratton RW, Musgrave SD, Dunn HO, Foote RH (1959) Influence of underfeeding and overfeeding from birth to 80 weeks of age on growth, sexual development, and semen production in Holstein bulls. Cornell Univ Expt Stn Bull 940
Brown BW (1993) Gonadotrophin and testosterone concentrations and testicular growth in rams supplemented with lupins from birth to puberty. Proc Aust Soc Reprod Biol 25, 34

Brown BW, Mattner PE, Panaretto BA, Brown $\mathrm{GH}$ (1989) Effect of mouse epidermal growth factor on plasma concentrations of LH, FSH and testosterone in rams. $J$ Reprod Fertil 87 , 649-655

Cameron AWN, Murphy PM, Oldham CM (1988) Nutrition of rams and output of spermatozoa. Proc Aust Soc Anim Prod 17, 162-165

Campbell GA, Kurcz M, Marshall S, Meites J (1977) Effects of starvation in rats on serum levels of follicle-stimulating hormone, luteinizing hormone, thyrotropin, growth hormone and prolactin; response to LH-releasing hormone and tryrotropin-releasing hormone. Endocrinology 100, 580-587

Claypool LE, Terasawa E (1989) $N$-methyl-D,Laspartate (NMDA) induces LHRH release as measured by in vivo push-pull perfusion in the stalk-median eminence of pre- and peripubertal female rhesus monkeys. Biol Reprod 40, suppl 1, 83, No 108

Comstock RE, Brady DE (1937) A study of characteristics of normal and abnormal semen of the sheep. Proc Am Soc Anim Sci 30, 233 238

Cooper TG, Waites GMH (1974) Testosterone in rete testis fluid and blood of rams and rats. $J$ Endocrinol 62, 619-629

Coulter GH, Kozub GC (1984) Testicular development, epididymal sperm reserves and seminal quality in two-year-old Hereford and Angus bulls: effect of two levels of dietary energy. J Anim Sci 59, 432-440

Courot M (1962) Développement du testicule chez l'agneau. Établissement de la spermatogenèse. Ann Biol Anim Biochim Biophys 2, 25-41

Courot M, de Reviers MM, Pelletier J (1975) Variation in pituitary and blood LH during puberty in the male lamb. Relation to time of birth. Ann Biol Anim Biochim Biophys 15, 509516

Courot M, Ortavant R (1981) Endocrine control of spermatogenesis in the ram. $J$ Reprod Fertil Suppl $30,47-60$

Courrier R, Raynaud R (1932) Modifications génitales chez les animaux à croissance arrêtée par la déficience en lysine. CR Soc Biol 109, 881.883 
Cunningham IJ, Hopkirk CSM (1935) Dietary protein in relation to sterility. $N Z J$ Sci Technol $17,420-432$

Cunningham IJ, Hopkirk CSM, Cunningham MM (1937) Further evidence of the relation of dietary protein to sterility. NZ J Sci Technol 19, 22-30

Davies DV, Mann T, Rowson LEA (1957) Effect of nutrition on the onset of male sex hormone activity and sperm formation in monozygous bull-calves. Proc $R$ Soc 147, 332-351

Dickerson JWT, Gresham GA, McCance RA (1964) The effect of undernutrition and rehabilitation on the development of the reproductive organs: pigs. J Endocrino/ 29, 111-118

Dunn RB (1955) Puberty in Merino rams. Aust Vet J31, 104-106

Dutt RH, Barnhart CE (1959) Effect of plane of nutrition upon reproductive performance of boars. J Anim Sci 18, 3-13

Dyrmundsson OR (1973) Puberty and early reproductive performance in sheep. II. Ram lambs. Anim Breed Abstr 41, 419-427

Dyrmundsson OR, Lees JL (1972) Puberal development of Clun Forest ram lambs in relation to time of birth. J Agric Sci 79, 83-89

Dziuk PJ, Bellows RA (1983) Management of reproduction of beef cattle, sheep and pigs. $J$ Anim Sci 57, Suppl 2, 355-379

Ebling FJP, Wood RI, Suttie JM, Foster DL (1989) An excitatory amino-acid agonist stimulates LH secretion in the growth-retarded hypogonadotropic lamb. Biol Reprod 40, Suppl 1, 83, No 106

Estienne MJ, Schillo KK, Hileman SM, Green MA, Hayes SH (1990) Effect of N-methyl-D,Laspartate on luteinizing hormone secretion in ovariectomized ewes in the absence and presence of estradiol. Biol Reprod 42, 126-130

Fels HE, Moir RJ, Rossiter RC (1959) Herbage intake of grazing sheep in south-western Australia. Aust J Agric Res 10, 237-247

Ferrell CL (1991) Nutritional influences on reproduction. In: Reproduction in Domestic Animals (PT Cupps, ed) Academic Press Inc, 4th ed, 577-603

Flipse RJ, Almquist JO (1961) Effect of total digestible nutrient intake from birth to four years of age on growth and reproductive development and performance of dairy bulls. J Dairy Sci 44, 905-914
Gauthier D, Berbigier $P$ (1982) The influence of nutritional levels and shade structure on testicular growth and hourly variations of plasma $\mathrm{LH}$ and testosterone levels in young Creole bulls in a tropical environment. Reprod Nutr Dev 22, 793-801

Gauthier D, Coulaud G (1986) Effect of underfeeding on testosterone-LH feedback in the bull. J Endocrino/ 110, 233-238

Gay VL, Plant TM (1987) N-methyl-D,L-aspartate elicits hypothalamic gonadotrophin-releasing hormone release in prepubertal male rhesus monkeys (Macaca mulatta). Endocrinology $120,2289-2296$

George JM, Turnbull KE (1966) The effect of redclover pasture on the reproductive tract of ram lambs. Aust J Agric Res 17, 919-922

Godwin KO, Platt BS (1960) Pathological changes in the pars anterior of the hypophysis of animals maintained on low-protein diets. Proc Nutr Soc 19, X

Gunn RMC, Sanders RN, Granger W (1942) Studies in fertility in sheep. 2. Seminal changes affecting fertility in rams. Bull Coun Sci Industr Res Aust No 148, 1-140

Hentges JF Jr (1967) Level of feeding and bull performance. In: Factors affecting calf crop (TJ Cunha, AC Warnick, M Koger, eds) Univ Florida Press, Gainesville, USA, 102-121

Hentges JF Jr, Capote FA, Neal FC (1964) Comparison of a self-fed concentrate and a supplemented forage diet for developing beef bulls. Anim Sci Mimeogr Ser Fla Agric Exp Stn AN64-12: $21 \mathrm{pp}$ Anim Breed Abstr 34, No 2052 (1966)

Hiroe K, Masaki J, Tomizuka T, Hanada A (1964) Effect of nutrition on the characteristics of young Holstein bull semen. Bull Nat Inst Anim Ind (Chiba) No 6, 1-10 Anim Breed Abstr 33, No 1200 (1965)

Hervey GR (1971) Physiological mechanisms for the regulation of energy balance. Proc Nutr Soc 30, 109-116

Hopwood ML, Gassner FX (1962) The free amino acids of bovine semen. Fertil Steril 13, 290303

Howland BE (1975) The influence of feed restriction and subsequent re-feeding on gonadotrophin secretion and serum testosterone levels in male rats. $J$ Reprod Fertil 44, 429436 
Jackson CM (1925) The effects of Inanition and Malnutrition upon Growth and Structure. Blakiston, Philadelphia

Jackson CM (1932) Structural changes when growth is suppressed by undernourishment in the albino rat. Am J Anat 51, 347-379

James JP (1950) The effect of level of nutrition on the sexual capacity of dairy bulls. Proc $N Z$ Soc Anim Prod 10, 84-88

Jansen HT, Khalid M, Jackson GL (1991) Nmethyl-D,L-aspartate induces a transient increase in LH secretion in the seasonally anestrous ewe. Domest Anim Endocrinol 8, 55-62

Jégou B, Dacheux JL, Terqui M, Garnier DH, Courot M (1978) Studies of the androgen binding protein in the rete testis fluid of the ram and its relation to sexual season. Mol Cell Endocrinol 9, 335-346

Jégou B, Dacheux JL, Garnier DH, Terqui M, Colas G, Courot M (1979) Biochemical and physiological studies of androgen-binding protein in the reproductive tract of the ram. $J$ Reprod Fertil 57, 311-318

Jöchle W, Lamond DR (1980) Effect of environment on reproduction. In: Control of Reproductive Functions in Domestic Animals. Martinus Nijhoff Publ, The Hague, 61-92

Johnson LA, Gerrits RJ, Bond J, Oltjen RR (1971) Growth and reproductive performance of bulls and heifers fed purified and natural diets. IV. Semen characteristics, body measurements and fertility of bulls (22 to 156 weeks of age). J Anim Sci 33, 808-813

Kato S, Harayama H (1990) Sexual maturation in Meishan boars. In: Chinese Pig Symposium (M Molenat, C Lagault, eds) Toulouse France July 5-6, INRA, Paris Publ, 36

Kemp B, Den Hartog LA (1989) The influence of energy and protein intake on the reproductive performance of the breeding boar: a review. Anim Reprod Sci 20, 103-115

Klatskin G, Salter WT, Humm FD (1947) Gynecomastia due to malnutrition. I. Clinical studies. Am J Med Sci 213, 19-30

Lamming GE (1969) Nutrition and reproduction. In: The Science of Nutrition of Farm Livestock. Part 1 (D Cuthbertson, ed) Pergamon Press, London, UK, 411-453

Lang J, Chan G, Xu J (1992) Sexual development and maturation of Jinhua boars. Proc Int Symp on Chinese Pig Breeds. Harbin,
China, August 11-14 (Chen Runheng, ed) Univ Press, Harbin Publ, 147-154

Laszczka A, Janasz M, Dudek E, Bielañski W (1969a) Effect of severe underfeeding upon the reproductive performance of bull. II. Semen characteristics. Bull Acad Pol Sci Ser Sci Biol $17,627-629$

Laszczka A, Biborski J, Szuperski T, Bielañski W (1969b) Effect of severe underfeeding upon the reproductive performance of bull. IV. The results of post-mortem examination. Pol Arch Weter 12, 35-52

Leathem JH (1970) Nutrition. In: The Testis (AD Johnson, WR Gomes, NL VanDemark, eds) III. Academic Press, New York, 169-205

Leathem JH (1975) Nutritional influences on testicular composition and function in mammals. Handb Physio/ Vol V, 225-232

Lincoln GA (1979) Pituitary control of the testis. $\mathrm{Br}$ Med Bull 35, 167-172

Lindner HR (1963) Partition of androgen between the lymph and venous blood of the testis in the ram. $J$ Endocrinol 25, 483-494

Lindsay DR, Gherardi PB, Oldham CM (1976) The effect of feeding a high protein supplement before joining on testicular volume of rams. Proc Int Congr Sheep Breeding (GJ Tomes, DE Robertson, RJ Lightfoot, eds) WAIT Press, Perth, 294-298

Lindsay DR, Pelletier J, Pisselet C, Courot M (1984) Changes in photoperiod and nutrition and their effect on testicular growth of rams. $J$ Reprod Fertil 71, 351-356

Lindsay DR, Martin GB, Williams IH (1990) Nutrition and reproduction. In: Animal reproduction - World animal science series (G King, ed) Elsevier, 1-31

Liu S, Chen Z, Lin G (1992) Studies on the reproductive physiology of Dahuabai swine. Proc Int Symp on Chinese Pig Breeds Harbin, China, August 11-14 (Chen Runheng, ed) Univ Press, Harbin Publ, 155-161

Lloyd Davies H (1982) Nitrogen metabolism in the ruminant. In: Nutrition and growth manual. Australian Universities International Development Program Publ, Hedges and Bell Pty Ltd, Melbourne, 40-45

Lutwak-Mann C, Mann T (1950) Restoration of secretory function in male accessory glands by vitamin $B$ deficient rats by means of chorionic gonadotrophin. Nature (Lond) 165, 556-557 
McClure TJ (1970) A review of developments in nutrition as it is related to fertility in cattle: 1964-9. NZ Vet J 18, 61-68

Mann T, Lutwak-Mann C (1951) Secretory function of male accessory organs of reproduction in mammals. Physiol Rev 31, 27-55

Mann T, Rowson LEA, Short RV, Skinner JD (1967) The relationship between nutrition and androgenic activity in pubescent twin calves, and the effect of orchitis. $J$ Endocrino/ 38, 455468

Mann T, Walton A (1953) The effect of underfeeding on the genital functions of a bull. $J$ Agric Sci 43, 343-347

Martin GB, Sutherland SRD, Lindsay DR (1987) Effects of nutritional supplements on testicular size and the secretion of LH and testosterone in Merino and Booroola rams. Anim Reprod Sci 12, 267-281

Martin GB, Tjondronegoro S, Adams NR (1989) Effect of changes in nutritional status on $\mathrm{LH}$ secretion in rams. Proc Aust Soc Reprod Biol 21,6

Martin GB, Ford JR, Purvis IW (1990) Environmental and genetic factors affecting reproductive activity in the Merino ram. In: Reproductive physiology of Merino sheep - concepts and consequences (CM Oidham, GB Martin, IW Purvis, eds). The University of Western Australia, 109-129

Mason KE (1939) Relation of the vitamins to the sex glands. In: Sex and Internal Secretions 2nd ed (E Allen, ed). The Williams and Wilkins Co, Baltimore, 1149-1212

Mason KE, Wolfe JM (1930) The physiological activity of the hypophyses of rats under various experimental conditions. Anat Rec 45, 232

Masters DG, Fels HE (1984) Seasonal changes in the testicular size of grazing rams. Proc Aust Soc Anim Prod 15, 444-447

Mattner PE, Braden AWH (1975) Studies of flock mating of sheep. 6 . The influence of age, hormone treatment, shearing and diet on the libido of Merino rams. Aust J Exp Agric Anim Husb 15, 330-336

Maun ME, Cahill WM, Davis RM (1945) Morphological studies of rats deprived of essential amino acids. I. Phenylalanine. Arch Pathol Lab Med 39, 294-300

Maun ME, Cahill WM, Davis RM (1946a) Morphological studies of rats deprived of essential amino acids. Il. Leucine. Arch Pathol Lab Med 40, 173-178

Maun ME, Cahill WM, Davis RM (1946b) Morphological studies of rats deprived of essential amino acids. III. Histidine. Arch Pathol Lab Med 41, 25-31

Meacham TN, Cunha TJ, Warnick AC, Hentges JF Jr, Hargrove DD (1963) Influence of low protein rations on growth and semen characteristics of young beef bulls. J Anim Sci 22, 115-120

Miles WR (1919) The sex expression of men living on a lowered nutritional level. J Nerv Ment Dis $49,208-224$

Millar R, Fairall N (1976) Hypothalamic, pituitary and gonadal hormone production in relation to nutrition in the male hyrax (Procavia capensis). J Reprod Fertil 47, 339-341

Mori A (1959) Studies on the reproductive failure of ram caused by underfeeding. 1 . On the effects of underfeeding upon the mating potency of ram, and the effects of normal feeding upon its recovery from impotence. Tohoku J Agric Res 10, 263-281

Moule GR (1961) The fertility of sheep grazing oestrogenic pastures. Aust Vet J $37,109-114$

Moule GR (1970) Australian research into reproduction in the ram. Anim Breed Abstr 38, 185202

Moule GR, Mattner PE (1961) Seminal degeneration induced in Merino rams by the administration of stilboestrol dipropionate. Nature (Lond) 192, 364-365

Moule GR, Braden AWH, Lamond DR (1963) The significance of oestrogens in pasture plants in relation to animal production. Anim Breed Abstr 31, 139-157

Moule GR, Braden AWH, Mattner PE (1966) Effects of season, nutrition and hormone treatment on the fructose content of ram semen. Aust J Agric Res 17, 923-931

Mulinos MG, Pomerantz L (1940) Pseudo-hypophysectomy a condition resembling hypophysectomy produced by malnutrition. J Nutr 19, 493-504

Mulinos MG, Pomerantz L (1941) The reproductive organs in malnutrition: effects of chorionic gonadotropin upon atrophic genitalia of underfed male rats. Endocrinology 29, 267-275

Murray PJ, Rowe JB, Pethick DW, Adams NR (1990) The effect of nutrition on testicular 
growth in the Merino ram. Aust $J$ Agric Res 41, 185-195

Mwansa PB, Makarechian M (1991) The effect of postweaning level of dietary energy on sex drive and semen quality of young beef bulls. Theriogenology 35, 1169-1178

Netesa A, Pashkevich A (1971) Effect of level of lysine in the diet on sperm production. Svinovodstvo, Moscow, USSR 10, 34 Nutr Abstr Rev 42, No 4737 (1972)

Niwa $T$ (1954) Studies on the spermatogenetic function in swine. Bull Nat Inst Agric Sci Ser G (Anim Husb) 8, 17-29

Nolan CJ, Neuendorff DA, Godfrey RW, Harms PG, Welsh TH Jr, McArthur NH, Randel RD (1990) influence of dietary energy intake on prepubertal development of Brahman bulls. J Anim Sci 68, 1087-1096

Okólski A, Szuperski T, Bielañski W (1971) Sexual behaviour and semen characteristics of rams during severe underfeeding. Bull Acad Pol Sci Ser Sci Biol 19, 701-705

Oldham CM, Adams NR, Gherardi PB, Lindsay $D R$, Mackintosh JB (1978) The influence of level of feed intake on sperm-producing capacity of testicular tissue in the ram. Aust J Agric Res 29, 173-179

Oltjen RR, Bond J, Gerrits RJ, Johnson LA (1971) Growth and reproductive performance of bulls and heifers fed purified and natural diets. $V$. Free amino acids in the semen and blood plasma of bulls (puberty to 148 weeks of age). J Anim Sci 33, 814-818

Pakenas PI, Pilipavicute JAS (1966) The effect of underfeeding for a considerable period on spermatogenesis in the bull. Cited in: Anim Breed Abstr 35, No 3579 (1967)

Parker GV, Thwaites CJ (1972) The effects of undernutrition on libido and semen quality in adult Merino rams. Aust J Agric Res 23, 109-115

Parr RA, Tilbrook AJ (1990) The influence of nutrition on circulating levels of testosterone in rams and testosterone-treated wethers. Proc Aust Soc Anim Prod 18, 328-331

Pazos R, Huggins C (1945) Effect of androgen on the prostate in starvation. Endocrinology 36, 416-425

Phillips RW, Andrews FN (1936) The development of the testes and scrotum of the ram, bull and boar. Mass Agric Exp Stn Bull No $331,1-16$
Platt BS, Stewart RJC (1967) Experimental protein-calorie deficiency: histopathological changes in the endocrine glands of pigs. $J$ Endocrinol 38, 121-143

Pomares CC, Galloway DB, Holmes JHG, Tilbrook AJ, Clarke IJ (1991) The effect of lupin and cowpea supplements on reproductive characteristics in rams. Proc Aust Soc Reprod $\mathrm{Biol} 23,80$

Pretorius PS, Marincowitz G (1968) Post-natal penis development, testes descent and puberty in Merino ram lambs on different planes of nutrition. S Afr J Agric Sci 11, 319-334

Pruitt RJ, Corah LR, Stevenson JS, Kiracofe GH (1986) Effect of energy intake after weaning on the sexual development of beef bulls. II. Age at first mating, age at puberty, testostone and scrotal circumference. J Anim Sci 63, 579-585

Ragab MT, Sharafeldin MA, Khalil IA (1966) Sexual behaviour of male lambs as affected by the plane of nutrition. J Anim Prod UAR 6, 89-94

Rattray PV (1977) Nutrition and reproductive efficiency. In: Reproduction in Domestic Animals 3rd edit (HH Cole, PT Cupps, eds). Academic Press Inc, London, 553-575

Reeves KR, Johnson BH (1976) Energy intake and testis function in prepuberal bulls. $J$ Anim Sci 42,264

Reid JT (1960) Effect of energy intake upon reproduction in farm animals. J Dairy Sci suppl 43, 103-122

Reid RL (1990) The Manual of Australian Agriculture. Butterworths, Sydney

Ritar AJ, Adams NR, Sanders MR (1984) Effect of Lupin feeding on $\mathrm{LH}$, testosterone and testes. In: Reproduction in Sheep (DR Lindsay, DT Pearce, eds) Aust Acad Sci and Aust Wool Corp Publ, Canberra, 76-78

Root AW, Russ RD (1972) Short-term effects of castration and starvation upon pituitary and serum levels of luteinizing hormone and follicle-stimulating hormone in male rats. Acta Endocrind 70, 665-675

Rowe JB, Murray PJ (1984) Production characteristics of rams given supplements containing different levels of protein and metabolisable energy. Proc Aust Soc Anim Prod 15, 565568

Rubner M (1919) Abstracts of Reports of Professor Rubner made in Reichgesuntheitrat, December 20th, 1917 Milit Surg 44, 237 and 405 
Russel AJF, MacDonald AJ, Kerr CD, Rudd B (1976) Changes in live weight and body condition of rams of three breeds throughout the year. Anim Prod 23, 73-80

Salamon S (1964) The effect of nutritional regimen on the potential semen production of rams. Aust J Agric Res 15, 645-656

Salter WT, Klatskin G, Humm FD (1947) Gynecomastia due to malnutrition. II. Endocrine studies. Am J Med Sci 213, 31-36

Samuels LT (1950) Relation of nutrition to the anterior pituitary gland. Progr Clin Endocrin 509

Schilling E, Krajnc A (1964) Intensive feeding of young bulls and its effect on ejaculate and testes. Züchtungskunde 37, 1-16. Anim Breed Abstr 33, No 2317 (1965)

Setchell BP, Waites GMH, Lindner HR (1965) Effect of undernutrition on testicular blood flow and metabolism and the output of testosterone in the ram. J Reprod Fertil 9, 149-162

Setchell BP, Hinks NT, Voglmayr JK, Scott TW (1967) Amino acids in ram testicular fluid and semen and their metabolism by spermatozoa. Biochem J 105, 1061-1065

Sharpe RM (1984) Intratesticular factors controlling testicular function. Biol Reprod 30, 29-49

Shettles LB (1960) The relation of dietary deficiencies to male fertility. Fertil Steril 11,88 89

Shirley RL, Meacham TN, Warnick AC, Hentges JF Jr, Cunha TJ (1963) Effect of dietary protein on fructose, citric acid and 5-nucleotidase activity in the semen of bulls. $J$ Anim Sci 22, 1418

Short RE, Adams DC (1988) Nutritional and hormonal interrelationships in beef cattle reproduction. Can J Anim Sci 68, 29-39

Siperstein DM (1921) The effects of acute and chronic inanition upon the development and structure of the testis in the albino rat. Anat Rec 20, 355-392

Skinner JD (1981) Nutrition, fertility in pedigree bulls. In: Environmental Factors in Mammalian Reproduction (D Gilmore, B Cook, eds). MacMillan Pub Ltd, London, 160-168

Skinner JD, Rowson LEA (1968) Puberty in Suffolk and cross-bred rams. J Reprod Fertil 16, 479-488

Spies TD (1958) Some recent advances in nutrition. J Am Med Assoc 167, 675-690
Srebnik HH, Nelson MM (1962) Anterior pituitary function in male rats deprived of dietary protein. Endocrinology 70, 723-730

Stepurin GF, Miruskina TN (1969) Effect of different amounts of amino acids on sperm production in boars. Tr Kishinev Sth Inst 58, 45 52 Nutr Abstr Rev 40, No 8578, 1970

Stevermer EJ, Kovacs MF Jr, Hoekstra WG, Self HL (1961) Effect of feed intake on semen characteristics and reproductive performance of mature boars. J Anim Sci 20, 858-865

Stewart SF, Kopia S, Gawlak DL (1975) Effect of underfeeding, hemigonadectomy, sex and cyproterone acetate on serum FSH levels in immature rats. J Reprod Fertil 45, 173-176

Sutherland SRD, Martin GB (1980) The effect of a supplement of lupin seed on the testicular size and LH profiles of Merino and Booroola rams. Proc Aust Soc Anim Prod 13, 459

Tjondronegoro S, Martin GB, Adams NR (1990) Effect of changes in nutritional status on FSH secretion in rams. Proc Aust Soc Reprod Biol 22, 7

Tjondronegoro S, Martin GB, Sutherland SRD, Boukliq R, Adams NR (1991) Effects of interactions between nutrition and negative feedback on the secretion of gonadotrophins in castrated Merino rams. Proc Aust Soc Reprod $\mathrm{Biol} 23,71$

Tommé MF, Loskutnikov PL (1972) Effect of methionine level in rations for adult breeding boars on metabolism and semen production. Dokl vses Ordena Lenina Akad S Nauk 7, 2325. Nutr Abstr Rev 43, No 2113 (1973)

Tribe DE, Cumming RB (1955) Nutrition and fertility in the bull. Vet Rev Annotat 1, 69-81

Underwood EJ, Somers M (1969) Studies in zinc nutrition in sheep. 1. The relation of zinc to growth, testicular development and spermatogenesis in young rams. Aust $J$ Agric Res $20,889-897$

VanDemark NL (1956) Quantitative aspects of semen production in bulls. Plenary papers. Proc Illrd Int Congr Anim Reprod 80-88

VanDemark NL, Mauger RE (1964) Effect of energy intake on reproductive performance of dairy bulls. I. Growth, reproductive organs and puberty. J Dairy Sci 47, 798-802

VanDemark NL, Fritz GR, Ewing LL, Mauger RE (1960) Limiting effects of underfeeding during growth on sperm production of mature bulls. J Anim Sci 19, 1338 
VanDemark NL, Fritz GR, Mauger RE (1964) Effect of energy intake on reproductive performance of dairy bulls. II. Semen production and replenishment. J Dairy Sci 47, 898904

Vitale R, Fawcett DW, Dym M (1973) The normal development of the blood-testis barrier and the effects of clomiphene and estrogen treatment. Anat Rec 176, 333-359

Voglmayr JK, Waites GMH, Setchell BP (1966) Studies on spermatozoa and fluid collected directly from the testis of the conscious ram. Nature (Lond) 210, 861-863

Walker DF (1967) Bull growth, management, and fertility. In: Factors Affecting Calf Crop (TJ Cunha, AC Warnick, M Koger, eds). Univ Florida Press, Gainesville, USA, 139-145

Wang A, Lan G, Guo Y, Qin S, Li B (1992) Preliminary studies on breed characteristics of Bama Xiang pig. 1. Feeding, growth and development and reproductive performance in Bama Xiang pig. Proc Int Symp on Chinese Pig Breeds. Harbin, China, August 11-14 (C Runheng, ed) Univ Press, Harbin Publ, 539542

Warnick AC, Meacham TN, Cunha TJ, Loggins PE, Hentges JF Jr, Shirley RL (1961) Effect of source and level of nitrogen on semen production and libido in rams. Proc IVth Int Congr
Anim Reprod Vol II, The Hague, Holland, 202211

Watanabe S, Dhariwal APS, McCann SM (1968) Effect of inhibitors of protein synthesis on the FSH-releasing action of hypothalamic extracts in vitro. Endocrinology 82, 674-684

Watson RH, Sapsford CS, McCance I (1956) The development of the testes, epididymis, and penis in the young Merino ram. Aust J Agric Res 7, 574-590

Wierzbowski S (1978) The sexual behaviour of experimentally underfed bulls. Appl Anim Ethol 4, 55-60

Willett EL, Ohms Jl (1957) Measurement of testicular size and its relation to production of spermatozoa by bulls. J Dairy Sci 40, 1559-1569

Wilson RC, Knobil E (1982) Acute effects of $N$ methyl-D,L-aspartate on the release of pituitary gonadotrophins and prolactin in the adult female rhesus monkey. Brain Res 248, 177179

Young JS (1974) Reproduction and nutrition in the beef herd. Proc Aust Soc Anim Prod 10, 45-54

Zirkin BR, Ewing LL, Kromann N, Cochran RC (1980) Testosterone secretion by rat, rabbit, guinea pig, dog and hamster testes perfused in vitro; correlation with Leydig cell ultrastructure. Endocrinology 107, 1867-1874 